\title{
Soft tissue metastases affecting the paravertebral and vertebral region from squamous cell carcinoma of the upper jaw: a case report
}

\author{
Paolo Cariati ${ }^{1}$, Kimberly Hawrylyshyn ${ }^{2}$, Daniel Pampin Ozan ${ }^{1}$, Luis Iñiguez de Ozoño ${ }^{3}$, \\ Susana Arroyo Rodriguez ${ }^{1}$ \\ ${ }^{1}$ Hospital General Universitario de Albacete, Oral and Maxillofacial Surgery Department, Albacete, Spain; ${ }^{2}$ Mount Sinai Hospital, Oral and \\ Maxillofacial Surgery Department, Toronto, Canada; ${ }^{3}$ Hospital General Universitario de Albacete, Pathological Anatomy Department, Albacete, \\ Spain \\ Correspondence to: Paolo Cariati, MD. Calle Hermanos Falco 37, 02006, Albacete, Spain. Email: paolocariati1@gmail.com.
}

\begin{abstract}
Background: Squamous cell carcinoma of the upper jaw is considered the least aggressive squamous cell carcinoma of the mouth and its tendency to metastasize is lower in comparison with other locations of the oral cavity. It usually metastasizes via the lymphatic system at cervical level and distant metastases are extremely uncommon. In this sense, only approximatively 50 cases of distant metastases have been described. Case Description: We report a case of oral squamous cell carcinoma soft tissue metastasis affecting the paravertebral and vertebral region in a 60-year-old patient with a squamous cell carcinoma of the upper jaw. Following careful analysis of the case by the tumor board, the patient was referred to the orthopedic department for evaluation, and ultimately underwent ablative surgery to remove the single soft tissue metastasis. Unfortunately, due to the aggressiveness of the disease patient died 2 months after the surgical removal of the soft tissue metastasis.

Conclusions: The main aim of this brief report is to describe this extremely rare location of distant metastases caused by a maxillary squamous cell carcinoma. Although squamous cell carcinoma of the upper jaw usually shows a better prognosis compared with other locations of the oral cavity, it might be particularly aggressive in certain patients.
\end{abstract}

Keywords: Soft tissue metastasis; squamous cell carcinoma; upper jaw; poor prognostic factor; case report

Received: 19 September 2020; Accepted: 04 February 2021; Published: 30 March 2021.

doi: $10.21037 /$ fomm-20-61

View this article at: http://dx.doi.org/10.21037/fomm-20-61

\section{Introduction}

Distant metastasis plays a critical role in the management and prognosis of oral squamous cell carcinoma (1). Regarding distant metastasis from oral cancer, the tongue is the most common primary site. Squamous cell carcinoma of the upper jaw is considered to be the least aggressive site of oral squamous cell carcinoma and shows a lower tendency to metastasize compared with other locations of the oral cavity (2). It usually spreads via the lymphatic system at the cervical level, and distant metastases are extremely uncommon. Approximatively 50 case of distant metastasis have been described in patients affected by maxillary squamous cell carcinoma. The lung was the most affected organ (3), followed by the rib (4), heart (5), skin (6) and vertebra (7). All these cases were reported in patients with advanced stage cancers (3).

\section{Case presentation}

We report the case of a 60 -year-old patient with oral squamous cell carcinoma of the upper jaw who developed soft tissue metastases affecting the paravertebral and vertebral region. The patient was initially referred to our department due to the presence of a chronic ulcer. Clinical 


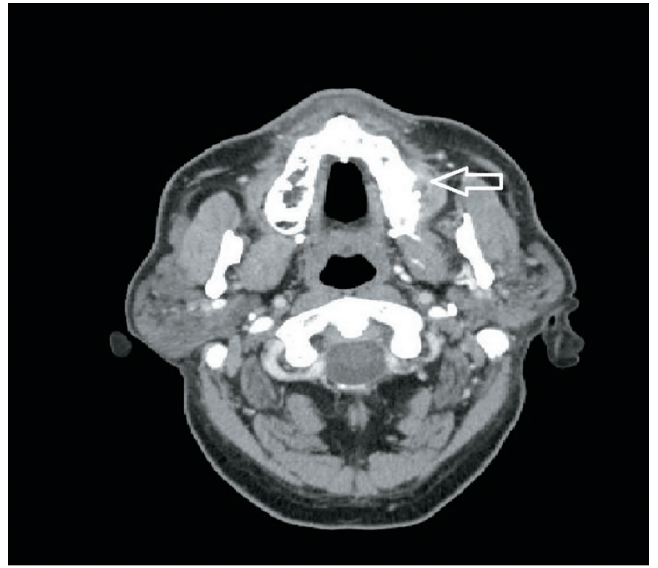

Figure 1 Computed tomography (CT) scans showing squamous cell carcinoma of the left maxilla and the bone erosion caused by the tumor (arrow).

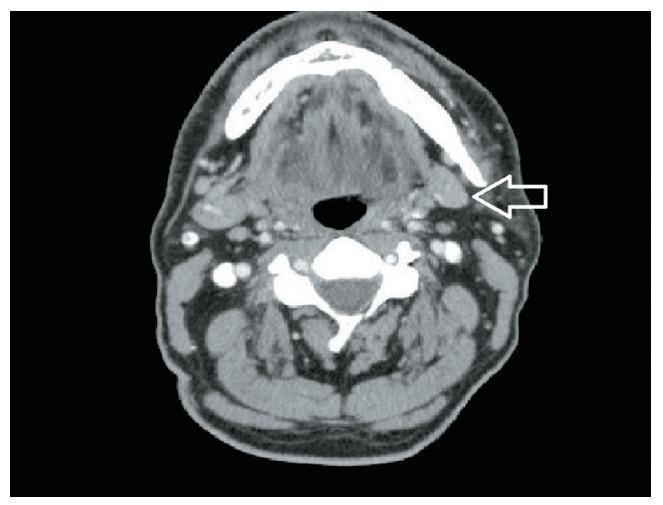

Figure 2 Computed tomography (CT) scan showing a suspicious node (arrow) involving left $1 \mathrm{~b}$ level.

examination showed a large ulcerated lesion involving the left maxillary gingiva $(3 \mathrm{~cm} \times 3 \mathrm{~cm}$, extended from tooth 24 to tooth 27) which approached the midline and infiltrated the maxillary bone (Figure 1). Histopathological analysis of the biopsy specimen demonstrated a poorly differentiated squamous cell carcinoma. Two suspicious cervical nodes with pathological criteria were observed on preoperative computed tomography (CT) scan and clinical exploration (Figure 2). Thus, the patient underwent hemi-maxillectomy and bilateral neck dissection. Three cervical nodes (left side) affected by squamous cell carcinoma were evidenced by the postoperative histopathological examination. Interestingly, one of these nodes demonstrated extracapsular spread. Consequently, the patient was staged as pT4N3M0. Due to the findings of the postoperative histopathological analysis,

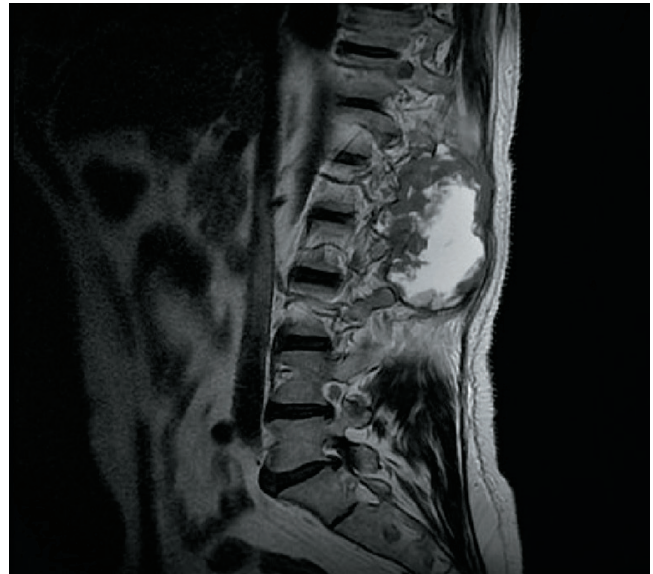

Figure 3 Magnetic resonance imaging (MRI) axial sagittal cut showing the extension of the paravertebral mass and the erosion of the transverse process of D12. The bone erosion of the vertebra begins from the external part of the transverse process and only minimally affects the inner part of it. This sign orientates the radiological suspicion of soft tissue metastasis. Indeed, bone destruction is more extensive in case the metastasis originates in the vertebra and secondarily affects the muscular plane. Specifically, vertebral metastases are often associated with the pathological fracture of the affected vertebra.

the tumor board decided to treat the patient with adjuvant radiotherapy and chemotherapy. Specifically, 37 cycles of radiotherapy (63 Gy) and three cycles of chemotherapy (cisplatin) were administered to the patient. However, 2 months after primary surgery and in the middle of radiation therapy, the patient developed a growing mass causing severe and continuous pain at the level of the paravertebral muscles of the lower back on the right side. $\mathrm{CT}$ and magnetic resonance imaging (MRI) scans revealed a mass infiltrating the paravertebral muscle (from D12 to L3) (Figure 3). Moreover, the mass extended toward the spinal canal causing erosion of the transverse process of D12. A fine needle aspirate biopsy showed tumor cells compatible with metastasis of oral squamous cell carcinoma (Figure 4). Importantly, after performing a positron emission tomography (PET) scan no other lesions were identified. Following careful analysis of the case by the tumor board, the patient was referred to the orthopedic department for evaluation, and ultimately underwent ablative surgery to remove the single soft tissue metastasis. Interestingly, a postoperative pathological report showed an extensive metastasis of oral squamous cell carcinoma (220 grams in weight). Thus, the patient underwent a further cycle of 


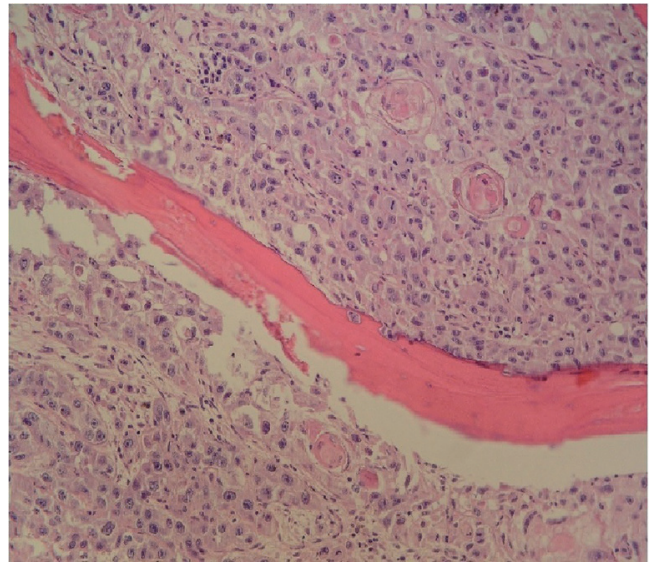

Figure 4 Pathological image of the soft tissue metastasis. Image shows a bone trabeculae, epithelial nests, numerous mitoses, and large atypical nucleoli. Staining method: hematoxylin-eosin.

systemic chemotherapy with nivolumab. Unfortunately, due to the aggressiveness of the disease patient died 2 months after the surgical removal of the soft tissue metastasis.

All procedures performed in studies involving human participants were in accordance with the ethical standards of the institutional and/or national research committee(s) and with the Helsinki Declaration (as revised in 2013). Written informed consent was obtained from the patient.

\section{Discussion}

Soft tissue metastases are extremely rare. To our knowledge, only few cases of soft tissue metastasis related to oral squamous cell carcinoma have been described in the current literature. The primary tumor that most frequently leads to soft tissue metastasis is lung cancer (8). Differential diagnosis of a soft tissue mass would include sarcoma, which can have a similar clinical and radiographic presentation (9). Thus, histopathological examination is mandatory to distinguish soft tissue metastasis from sarcoma. According to the literature, the most common location of soft tissue metastases is the back, followed by the paraspinal musculature, chest wall, abdominal wall, thigh, and iliopsoas. In contrast, sarcomas usually affect the thigh (in almost $50 \%$ of cases) followed by the back, upper limb and retroperitoneum. Another important clinical difference between soft tissue metastasis and sarcomas is pain. Soft tissue metastases are painful in approximately $83 \%$ of patients, while sarcomas are usually painless. Clinical suspicion, CT scan, MRI and fine needle aspirate biopsy are essential for guiding the diagnosis. A careful radiological analysis is also helpful to differentiate between vertebral metastasis extended to the paravertebral space and soft tissue metastasis. Indeed, bone destruction is more extensive in case the metastasis originates in the vertebra and secondarily affects the muscular plane. Specifically, vertebral metastases are often associated with the pathological fracture of the affected vertebra $(7,10)$. A definitive diagnosis is only possible with postoperative histopathological examination of the lesion (11).

Interestingly, all cases of distant metastasis reported in patients affected by oral squamous cell carcinoma showed previous cervical involvement. This might suggest that tumors develop the capacity to generate distant metastasis only after affecting the neck. The presence of soft tissue metastasis indicates very poor prognosis. However, in cases of a single isolated metastasis, surgical removal is advised to improve the patient's quality of life and life expectancy. In cases where the lesion cannot be extirpated, the patient should be referred for palliative care in order to control the pain. The main aim of this brief report is to describe this extremely rare location of distant metastases. Although squamous cell carcinoma of the upper jaw is considered to be less aggressive compared with other locations of the oral cavity, it has the potential to metastasize and may behave aggressively in certain patient populations. A close followup is mandatory in all patients affected by this disease.

\section{Acknowledgments}

Funding: None.

\section{Footnote}

Peer Review File: Available at https://fomm.amegroups.com/ article/view/10.21037/fomm-20-61/prf

Conflicts of Interest: All authors have completed the ICMJE uniform disclosure form (available at https://fomm. amegroups.com/article/view/10.21037/fomm-20-61/coif). PC serves as an unpaid editorial board member of Frontiers of Oral and Maxillofacial Medicine from Apr 2020 to Mar 2022. The other authors have no conflicts of interest to declare.

Etbical Statement: The authors are accountable for all aspects of the work in ensuring that questions related to the accuracy or integrity of any part of the work are 
appropriately investigated and resolved. All procedures performed in studies involving human participants were in accordance with the ethical standards of the institutional and/or national research committee(s) and with the Helsinki Declaration (as revised in 2013). Written informed consent was obtained from the patient.

Open Access Statement: This is an Open Access article distributed in accordance with the Creative Commons Attribution-NonCommercial-NoDerivs 4.0 International License (CC BY-NC-ND 4.0), which permits the noncommercial replication and distribution of the article with the strict proviso that no changes or edits are made and the original work is properly cited (including links to both the formal publication through the relevant DOI and the license). See: https://creativecommons.org/licenses/by-nc-nd/4.0/.

\section{References}

1. Hakim SG, Steller D, Sieg P, et al. Clinical course and survival in patients with squamous cell carcinoma of the maxillary alveolus and hard palate: Results from a singlecenter prospective cohort. J Craniomaxillofac Surg 2020;48:111-6.

2. Sekikawa S, Kawachi H, Ogane S, et al. Which Factors Affect the Long-Term Survival of Patients With Oral Squamous Cell Carcinoma With Distant Metastasis? J Oral Maxillofac Surg 2020;78:469-78.

3. Irani S. Distant metastasis from oral cancer: A review and

\section{doi: $10.21037 /$ fomm-20-61}

Cite this article as: Cariati P, Hawrylyshyn K, Pampin Ozan D, Iñiguez de Ozoño L, Arroyo Rodriguez S. Soft tissue metastases affecting the paravertebral and vertebral region from squamous cell carcinoma of the upper jaw: a case report. Front Oral Maxillofac Med 2021;3:10. molecular biologic aspects. J Int Soc Prev Community Dent 2016;6:265-71.

4. Mathew BS, Jayasree K, Madhavan J, et al. Skeletal metastases and bone marrow infiltration from squamous cell carcinoma of the buccal mucosa. Oral Oncol 1997;33:454-5.

5. Kim JK, Sindhu K, Bakst RL. Cardiac Metastasis in a Patient with Head and Neck Cancer: A Case Report and Review of the Literature. Case Rep Otolaryngol 2019;2019:9581259.

6. Sun J, Gao Q, Fan VT. Multifocal cutaneous metastases from squamous cell carcinoma of hard palate. Int J Oral Maxillofac Surg 2012;41:807-9.

7. Carlson ER, Ord RA. Vertebral metastases from oral squamous cell carcinoma. J Oral Maxillofac Surg 2002;60:858-62.

8. Baldeo C, Ali R, Seeram V, et al. Lung cancer presenting as a soft-tissue metastasis. Case Rep Oncol 2015;8:185-8.

9. Hu SC, Chen GS, Lu YW, et al. Cutaneous metastases from different internal malignancies: a clinical and prognostic appraisal. J Eur Acad Dermatol Venereol 2008;22:735-40.

10. Cariati P, Pampin Ozan D, Arroyo Rodriguez S. Vertebral metastasis from squamous cell carcinoma of the tongue. Front Oral Maxillofac Med 2020;2:8.

11. Quint LE, Tummala S, Brisson LJ, et al. Distribution of distant metastases from newly diagnosed non-small cell lung cancer. Ann Thorac Surg 1996;62:246-50. 